\title{
INCOME OVER FEED COST FOR SMALL- TO MEDIUM-SCALE BEEF CATTLE FATTENING OPERATIONS IN EAST JAVA
}

\author{
A. Priyanti ${ }^{1}$, I.G.A.P. Mahendri ${ }^{1}$, F. Cahyadi ${ }^{2}$ and R. A. Cramb ${ }^{3}$ \\ ${ }^{1}$ Indonesian Center for Animal Research and Development, Bogor \\ ${ }^{2}$ Junior Scientist, ACIAR LPS/038/2008, Pasuruan-East Java \\ J. Raya Padjadjaran Kav E-59, Bogor 16151 - Indonesia \\ ${ }^{3}$ School of Agriculture and Food Sciences, University of Queensland \\ St Lucia Campus, 4072 Australia \\ Corresponding E-mail: atienpriyanti@yahoo.com
}

Received Juni 27, 2012; Accepted August 05, 2012

\begin{abstract}
ABSTRAK
Penelitian untuk mengetahui keuntungan usaha penggemukan sapi telah dilakukan di Jawa Timur. Penelitian bertujuan untuk menganalisis pendapatan atas biaya pakan melalui pemberian pakan lokal. Penelitian dilakukan pada periode Juli-September 2010 dan Januari-Maret 2011, masing-masing merepresentasikan musim hujan dan kemarau. Bangsa sapi yang digunakan adalah sapi PO dan sapi persilangan PO dengan Simental (SimPO) dan Limousin (LimPO). Usaha ini meliputi peternakan rakyat dan skala medium, masing-masing memiliki 1-2 dan 10-20 ekor sapi jantan per peternak. Periode yang diamati adalah 58 hari dan 46 hari pada musim kemarau dan penghujan dengan parameter pertambahan bobot sapi, jumlah pakan serta harga input dan output. Rata-rata pertambahan bobot badan dan pendapatan atas biaya pakan dianalisis dengan uji-t yang menunjukkan bahwa pada peternakan rakyat sapi SimPO memberikan pendapatan atas biaya pakan yang signifikan paling tinggi dibandingkan dengan PO dan LimPO, sedangkan skala medium dicapai oleh sapi LimPO. Usaha penggemukan pada peternakan rakyat menghasilkan pendapatan atas biaya pakan yang hampir sama atau lebih tinggi dibandingkan dengan skala medium pada musim kemarau dan penghujan. Usaha skala medium harus mengeluarkan biaya pakan hampir mencapai $70 \%$ dengan perolehan bobot badan hampir sama pada usaha peternakan rakyat. Usaha penggemukan sapi persilangan di tingkat peternakan rakyat mampu bersaing secara ekonomis dengan usaha skala medium.

Kata kunci: Pendapatan atas biaya pakan, penggemukan sapi, sapi lokal, sapi persilangan, Jawa Timur.

ABSTRACT

An evaluation was conducted of the returns to fattening cattle of small- and medium-scale enterprises in East Java. The objective was to analyze income over feed costs (IOFC) based on locally available feedstuffs to increase liveweight gain. The study was conducted during July-September 2010 and January-March 2011, representing relative dry and wet season. The breeds were PO and Limousin and Simmental crossed with PO (LimPO and SimPO). Small-scale farmers owning 1-2 bulls and medium-scale farmers fattening 10-20 bulls in one period. Fattening period was 58 and 46 days, respectively for dry and wet season. Monthly measurements included liveweight, feed intake, input and output prices. Mean values of growth rates and IOFC were compared using t-tests. The results indicated that, for small-scale operations, SimPO bulls gave a significantly higher return than either PO or LimPO bulls. Likewise, LimPO gave a higher IOFC than SimPO in medium-scale operations. Small-scale farmers achieved equal or higher IOFC for European-cross than medium-scale farmers in both seasons. This reflects that cash outlays for feed were about two-thirds that of medium-scale operations while daily growth rates were similar. Small-scale fattening operations using European-cross can be financially competitive with medium-scale operations in both wet and dry seasons.
\end{abstract}

Keywords: Income over feed cost, cattle fattening, local cattle, crossbred cattle, East Java 


\section{INTRODUCTION}

The value of livestock produced in East Java by 2010 was IDR 8,170 billion (in 2000 prices), the highest among Indonesia's 33 provinces and accounting for $33.6 \%$ of Indonesia's total livestock GDP (Badan Pusat Statistik, 2011). Livestock production directly supports rural livelihoods, with approximately 1.9 million households involved in livestock farming (Ditjen Peternakan, 2010). East Java has the largest number of beef cattle in Indonesia, accounting for $32 \%$, as reported by the recent livestock census (Kementan-BPS, 2011). In pursuit of Indonesia's beef self-sufficiency, the Provincial Government of East Java launched a program called 'Sapi Berlian' with the aim of producing 5 million calves within 5 years. This program is an enhancement of the previous program to provide artificial insemination for one million cows. It has been projected that to meet the targets of the Sapi Berlian program beef production would have to increase by $2.67 \%$ per year, requiring extraordinary actions to be realized (Kadir, 2009).

Beef cattle production in East Java is mainly in the hands of small farmers with 1-2 cattle, but there are also some medium-scale fattening enterprises of 10-20 cattle and a few large, commercial-scale operations of more than 3,000 cattle. There has been an increase in small- and medium-scale cattle fattening operations in East Java, with 10-20 bulls fattened during a production period.

The small- and medium-scale enterprises are still more dependent on low-input feeding systems with limited or no cash inputs. Hanifah et al. (2010) stated that the use of rice straw by farmers in East Java involves drying the straw for 3-4 days and storing it in lofts over feeding pens. Other feeds such as rice bran, molasses, tofu waste, and cassava are also fed to the cattle, but these are mostly for dedicated fattening operations. Feed costs typically represent $70 \%$ of the production cost in producing beef. As a necessary step to remain profitable, beef cattle producers should be monitoring and making decisions based initially on the 'income over feed costs' (IOFC). This measure does not account for differences in the investment necessary to support the production system. IOFC is a gross margin concept that can be used as a preliminary indicator of whether the fattening operation is viable in the short run. Ishler (2010) reported that income over feed cost could be used to manage profitability in a typical dairy cattle operation with large seasonal variation in milk production. It would be expected that the measure would be similarly useful in a beef cattle fattening operation.

The objective of this study was to analyze the IOFC realized by cattle-fattening operations in East Java using feeding strategies based on local feed sources of the farmers. It was hypothesized that IOFC would differ between (1) small- and medium-scale operations; (2) PO and Europeancross breeds; and (3) wet and dry seasons.

\section{MATERIALS AND METHODS}

Experiments were conducted in the Districts of Malang, Pasuruan, and Probolinggo. This allowed observation of cattle-fattening operations within the context of different feed resources and management systems, including both small- and medium-scale operations. Small-scale producers owned 1-2 bulls while medium-scale producers fattened 10-20 bulls in one period. The cattle breeds included local Ongole cattle (PO) and European crossbred cattle, namely, Limousin and Simmental with PO (LimPO and SimPO). None of the medium-scale farmers fattened PO cattle (Table 1).

A total of 93 cattle belonging to 60 farmers were monitored during the study (Table 1). A survey of the participating farmers was also conducted. There were 42 small-scale farmers and 18 medium-scale farmers, with $27 \mathrm{PO}, 36 \mathrm{LimPO}$, and 30 SimPO cattle. None of the medium-scale producers had PO cattle. The study was conducted during two periods, July-September 2010, representing the dry season, and January-March 2011, representing the wet season. The period of fattening was 58 days in the dry season and 46 days in the wet season. The variables measured by

Table 1. Number of Bulls and Farmers Involved in the Study*

\begin{tabular}{lccc}
\hline Fattening & \multicolumn{3}{c}{ Cattle Breed } \\
\cline { 2 - 4 } Operation & PO & SimPO & LimPO \\
\hline Small & $27(22)$ & $12(11)$ & $9(9)$ \\
Medium & - & $24(8)$ & $21(10)$ \\
Total & $27(22)$ & $36(19)$ & $30(19)$ \\
\hline
\end{tabular}

*Number of farmers in brackets. 
monthly monitoring included the weight, hence growth rate of the bulls, the amount of feed offered, and input and output prices. Feed offered averaged $10 \%$ of the cattle's bodyweight per day.

IOFC was measured in rupiah per bull per day. Following Bailey et al. (2009), the IOFC is defined by the equation:

$\mathrm{IOFC}=$ PLW $x$ ADG - DFC,

where

IOFC = income over feed cost (IDR/bull/day)

PLW = farm-gate price of liveweight bull (IDR/kg)

$\mathrm{ADG}=$ average daily gain $(\mathrm{kg})$

$\mathrm{DFC}=$ daily feed cost (IDR/bull)

The IOFC data gathered were subjected to analysis of variance (ANOVA) using the general linear model (SAS, 2006).

\section{RESULTS AND DISSCUSION}

\section{Farmers' Characteristics}

The farmers' characteristics were similar to those of cattle producers in general, including age (averaging 47 and 41 years respectively for husband and wife) and education level (elementary school only). The average household size was 4.1 persons, suggesting that family labor was available to help manage the cattle operation, though most of the family members were in schooling. Farmers' experience in fattening operations was much less compared to their experience in cattle production in general, averaging 5.3 years compared with 16.2 years. Besides farming, off-farm or non-farm wage work was common as a secondary job.

Farmers owned almost 1 ha of land on average, of which only one third was paddy land. Most of farmers (68\%) did not own paddy land, only dry land and house yard. The most common crops planted in this land were food crops, with three crops per year of rice and/or maize in the paddy fields, and maize and cassava in the dryland fields. On average, farmers managed 3.4 cattle of which $39.5 \%$ were young bulls. At the time of interview, most of the farmers were willing to have more bulls for fattening, up to 3.6 young bulls on average. The main reasons for not reaching this capacity were limited income (43\%) and the high price of young bulls (34\%). Almost $60 \%$ of the farmers fattened young European cross bulls (LimPO and SimPO) due to the higher price they bring and the faster growth rate compared to the PO. This indicated the business orientation of the farmers.
In terms of the period of the fattening operation, most of the small-scale farmers reported that there was no specific period of time to sell the fattened bulls. They kept them for an average of 24 months before selling. The medium-scale farmers, who were more specialized, fattened their animals for an average of 6-8 months.

\section{Expenditure on Feed}

During the wet season, all of the farmers used grasses (native grass as well as planted elephant grass) to feed the bulls. In the dry season, $93 \%$ of the farmers used rice straw as the basal diet. About $41 \%$ of the farmers fed gliricidia and leucaena and $40 \%$ used corn stover if rice straw was not available. Very few small-scale farmers gave feed supplements (mostly salt and, very rarely, rice bran). Among the medium-scale farmers, the most common feed supplements given were rice bran $(76 \%)$, cassava $(19 \%)$, and tofu waste $(5 \%)$. The ration of these feed supplements changed over time depending on their relative prices. At the time of interview, the price of rice bran was considered expensive at IDR $2,500 / \mathrm{kg}$.

Table 2 shows the average daily expenditure on feed by category of operation. Note that this does not include feeds collected by the farmer at no monetary cost. The lowest expenditure was incurred in the dry season by small-scale farmers who raised PO bulls (about IDR 3,500). In general, small-scale farmers expended IDR 4,0006,000 for feeding LimPO and SimPO bulls, with no consistent differences between wet and dry seasons. Medium-scale farmers incurred higher average expenditure on feed, averaging between IDR7,000 and IDR 7,500 for both LimPO and SimPO bulls in both dry and wet season. In the medium-scale operations, feed inputs were almost entirely dependent on purchasing feed resources, for concentrates and grasses as well as rice straw. These estimates for feed expenditure were low compared to previous studies that found expenditure to be in the range of IDR 10,00016,000/head for LimPO and SimPO cattle under cooperative fattening operations in Yogyakarta and Central Java (Soeharsono et al., 2011).

\section{Growth Rates}

Table 3 shows the average daily growth rates (ADG) during the dry season. As expected, PO bulls (in small-scale operations) showed the lowest growth rate at $0.14 \mathrm{~kg} / \mathrm{d}$. Small-scale 
Table 2. Average Feed Expenditure per Day by Scale of Fattening Operation, Breed, and Season (IDR/bull/day)

\begin{tabular}{llccc}
\hline \multirow{2}{*}{ Fattening Operation } & Period of Fattening & \multicolumn{3}{c}{ Cattle Breed } \\
\cline { 3 - 5 } & & PO & LimPO & SimPO \\
\hline Small-scale & I. July-September & 3684 & 5343 & 4764 \\
& II. January-March & 4768 & 6087 & 4207 \\
& & & & \\
Medium-scale & I. July-September & NA & 7425 & 7540 \\
& II. January-March & NA & 7391 & 7476 \\
\hline
\end{tabular}

NA : no medium farmers raised PO for fattening

farmers achieved significantly higher ADG with SimPO bulls, averaging $0.41 \mathrm{~kg} / \mathrm{d}$. For mediumscale operations, there was no significant difference in ADG between breeds (LimPO and SimPO), at $0.35-0.40 \mathrm{~kg} / \mathrm{d}$. This considered a low gain for crossbred cattle due to price of cattle liveweight was low at the time, while that of feed price was high. Farmer had not given optimal feed on this operation. Most important, there was no significant difference between the growth rates achieved by small- and medium-scale farmers with the same breeds.

Growth rates were no different during the wet season (Table 4). Again, the mean ADG of PO cattle was significantly lower than for the European crosses at $0.21 \mathrm{~kg} / \mathrm{d}$, though the growth of LimPO cattle in small-scale operations was only somewhat higher at $0.26 \mathrm{~kg} / \mathrm{d}$ and the difference was not significant at the $10 \%$ level $(\mathrm{P}=0.0138)$ due to a large standard error. SimPO cattle in small-scale operations achieved 0.41 $\mathrm{kg} / \mathrm{d}$, which was significantly higher than for PO $(\mathrm{P}<0.01)$. There was no significant difference between LimPO and SimPO cattle, whether in small-scale or medium-scale operations.

The growth rates for the study was found similar to previous study by Rianto et al. (2004) which liveweight gains of $\mathrm{PO}$ and LimPO were significantly different $(\mathrm{P}<0.05)$ being 0.24 and $0.47 \mathrm{~kg} /$ day. The experiment used bulls that were fed fermented rice straw provided ad libitum and given concentrate of $2.1 \%$ body weight. Likewise, Lestari et al. (2011) has found that average daily gain of Java bull and Ongole crossbred under intensive feeding management was not significantly different $(\mathrm{P}>0.05)$ of being $0.58 \mathrm{~kg}$ and $0.78 \mathrm{~kg}$, respectively. Sahidah (2000) in Astuti (2004) stated that body weight of PO male aged 2-3 years have reached 201-366 kg with the daily gain of $0.62 \mathrm{~kg}$. In addition, Purnomoadi et al. (2007) reported that Ongole crossbred bulls fed by ad libitum rice straw combine with $50 \%$ and $70 \%$ concentrate supplementation yield daily body weight gain of $0.45 \mathrm{~kg}$ and $0.62 \mathrm{~kg}$, respectively. The much lower daily growth rate and feed expenditure for PO cattle in this study may indicate that these small-scale operations are not genuine fattening operations but just the way farmers keep bulls until around 3 years to sell when they need cash. However, the expenditure on feed and the daily growth rates achieved by European crosses in the medium-scale operations were also relatively low. The growth rates of these breeds were no different between small- and medium-scale.

\section{Income over Feed Costs (IOFC)}

Weller (1994) reported that liveweight gain is highly correlated with feed efficiency for growing animals. The average daily growth rates had a direct effect on the IOFC achieved in these fattening operations. Table 5 shows the results for IOFC for different breeds and scales in the dry season. For small-scale farmers, the IOFC for European cross cattle was three to four times that of PO cattle, with the mean for SimPO cattle significantly higher than $\mathrm{PO}(\mathrm{P}<0.10)$ at 344,000 IDR/period. This was because the growth rate of SimPO cattle was higher than that of PO cattle, and this growth rate was more than sufficient to offset the greater expenditure on feed. This finding was similar to a previous study by 
Table 3. Means and Standard Errors (SE) of ADG (kg/d) during Dry Season for Different Breeds and Scales of Operation

\begin{tabular}{llccc}
\hline \multicolumn{1}{r}{ Cattle Breed } & \multicolumn{1}{c}{ Scale of Operation } & Mean & SE & Prob $>|\mathrm{t}|$ \\
\hline PO & Small-scale & $0.1379^{\mathrm{a}}$ & 0.05580 & 0.0154 \\
LimPO & Small-scale & $0.2941^{\mathrm{ab}}$ & 0.09665 & 0.0031 \\
& Medium-scale & $0.3912^{\mathrm{b}}$ & 0.06327 & $<.0001$ \\
\multirow{2}{*}{ SimPO } & Small-scale & $0.4102^{\mathrm{b}}$ & 0.08371 & $<.0001$ \\
& Medium-scale & $0.3535^{\mathrm{b}}$ & 0.05919 & $<.0001$ \\
\hline
\end{tabular}

Means in the same column with different superscripts are significantly different $(\mathrm{P}<0.05)$

Table 4. Means and Standard Errors (SE) of ADG (kg/d) during Wet Season for Different Breeds and Scales of Operation

\begin{tabular}{llccc}
\hline \multicolumn{1}{r}{ Cattle breed } & \multicolumn{1}{c}{ Scale of operation } & Mean & SE & Prob $>|\mathrm{t}|$ \\
\hline PO & Small-scale & $0.2143^{\mathrm{a}}$ & 0.05303 & 0.0001 \\
LimPO & Small-scale & $0.2609^{\mathrm{ab}}$ & 0.10414 & 0.0138 \\
& Medium-scale & $0.4278^{\mathrm{b}}$ & 0.05031 & $<.0001$ \\
\multirow{2}{*}{ SimPO } & Small-scale & $0.4146^{\mathrm{b}}$ & 0.08713 & $<.0001$ \\
& Medium-scale & $0.3295^{\mathrm{b}}$ & 0.04871 & $<.0001$ \\
\hline
\end{tabular}

Means in the same column with different superscripts are significantly different $(\mathrm{P}<0.05)$

Table 5. Mean and Standard Error (SE) of IOFC during Dry Season for Different Breeds and Scales of Operation (IDR)

\begin{tabular}{llrrc}
\hline \multicolumn{1}{c}{ Cattle Breed } & \multicolumn{1}{c}{ Scale of Operation } & Mean & SE & Prob $>|\mathrm{t}|$ \\
\hline PO & Small-scale & $83,804^{\mathrm{a}}$ & 67,924 & 0.2206 \\
LimPO & Small-scale & $234,565^{\mathrm{ab}}$ & 117,647 & 0.0493 \\
& Medium-scale & $145,171^{\mathrm{ab}}$ & 77,018 & 0.0627 \\
\multirow{2}{*}{ SimPO } & Small-scale & $344,296^{\mathrm{b}}$ & 101,886 & 0.0011 \\
& Medium-scale & $111,196^{\mathrm{a}}$ & 72,044 & 0.1263 \\
\hline
\end{tabular}

Means in the same column with different superscripts are significantly different $(\mathrm{P}<0.05)$

Prasetiyono et al. (2007) that shown beef cattle fed by ad libitum rice straw supplemented by rice bran and cassava-urea complex has given IOFC of IDR 7,500/head/day with daily gain of $0.85 / \mathrm{kg} /$ day. In comparison, Mayulu et al. (2009) had reported that Simmental crossbred beef cattle has given the highest IOFC of IDR $18,391 /$ head/day being fed by complete feed based on ammoniated fermented rice straw. These figures indicated that changes in feed price due to changes in feedstuff influenced cattle performance, i.e. growth rate, and was a significant factor contributing to fluctuations in cattle finishing cost of gains and its profit.

Small-scale farmers also achieved higher IOFC than medium-scale operations for both 
Table 6. Mean and Standard Error (SE) of IOFC during Wet Season for Different Breeds and Scales of Operation (IDR)

\begin{tabular}{llccc}
\hline \multicolumn{1}{c}{ Cattle breed } & \multicolumn{1}{c}{ Scale of operation } & Mean & SE & Prob $>|\mathrm{t}|$ \\
\hline PO & Small-scale & $102,022^{\mathrm{ab}}$ & 41,627 & 0.0159 \\
LimPO & Small-scale & $79,585^{\mathrm{ab}}$ & 70,889 & 0.2641 \\
& Medium-scale & $122,647^{\mathrm{ab}}$ & 40,262 & 0.0029 \\
\multirow{2}{*}{ SimPO } & Small-scale & $216,780^{\mathrm{b}}$ & 70,889 & 0.0028 \\
& Medium-scale & $67,110^{\mathrm{a}}$ & 40,927 & 0.1041 \\
\hline
\end{tabular}

Means in the same column with different superscripts are significantly different $(\mathrm{P}<0.05)$

LimPO and SimPO, with small-scale SimPO operations achieving the highest IOFC overall, significantly different from the medium-scale operation $(\mathrm{P}<0.05)$. Small-scale farmers had less expenditure on feed, which mostly consisted of grasses and agricultural by-products for which there was no cash outlay.

For medium-scale fattening operations, IOFC for LimPO bulls was significantly higher than for SimPO bulls $(\mathrm{P}<0.10)$. Soeharsono et al. (2010) have shown that the income above variable cost of LimPO and SimPO medium-scale fattening operations in Central Java was higher than this figure. The difference was due to the lower growth rates achieved by farmers in this study, presumably related to lower expenditure on feed.

The results for the wet season are shown in Table 6. Small-scale farmers again achieved significantly higher returns to fattening SimPO bulls (IDR 217,000) than either LimPO or PO bulls, and this return was significantly higher than that achieved by medium-scale operations for both SimPO and LimPO bulls. There was no clear-cut pattern between seasons. The small-scale farmers achieved somewhat higher returns for PO bulls but lower returns for the European cross bulls than in the dry season. The medium-scale farmers achieved somewhat lower returns for both European-cross breeds than in the dry season. In East Java, there is reasonably good rain throughout the year and farmers do not have difficulty in finding grasses to cut and carry during wet and dry seasons.

Table 6 has shown that IOFC of the LimPO was the highest and significantly different $(\mathrm{P}<0.01)$. This finding had similar pattern with that one during the dry season, only the magnitude that make a difference. SimPO's IOFC at the farmers' operation was higher and significantly different to the medium scale of operation. This indicates that daily cost of feed at farmers' level was lower and could be compensated by its gain on growth, so that the revenue was considered higher.

\section{CONCLUSIONS}

The characteristics of farmers running small-scale beef cattle fattening operations in East Java are similar to those of cattle growing and cow-calf operations in the same districts. The distinguishing features of medium-scale farmers fattening operations were higher level of education and number of cattle owned. Feed expenditure by small-scale farmers was higher for European crosses than PO bulls. The daily growth rate of the crossbred was higher than PO cattle, which were only fattened in small-scale operations. At the small-scale operations, SimPO bulls gave a significantly higher return than either PO or LimPO bulls, likewise LimPO bulls gave a higher IOFC than SimPO bulls in medium-scale operations. This reflects that cash outlays for feed were about two-thirds that of medium-scale operations while the daily growth rates were similar. Nevertheless, small-scale fattening operations using European cross can be financially competitive with medium-scale operations in wet and dry seasons

\section{ACKNOWLEDGMENTS}

The authors are grateful for the financial 
supported for this research provided through ACIAR Project LPS/2008/038. This project will contribute significantly to more efficient cattle management practices for the small farmers of East Java.

\section{REFERENCES}

Astuti, M. 2004. Potensi dan keragaman sumberdaya genetik sapi Peranakan Ongole (PO). Wartazoa. 14 (3): 98-106.

Badan Pusat Satistik. 2011. Statistik Indonesia. Badan Pusat Statistik, Jakarta.

Bailey, K., T. Beck, E. Cowan and V. Ishler. 2009. Dairy Risk - Management Education: Managing Income Over Feed Costs. Agricultural Communications and Marketing, The Pennsylvania State University, PA, USA.

Ditjen Peternakan. 2010. Statitsik Peternakan 2010. Direktorat Jenderal Peternakan, Kementerian Pertanian RI, Jakarta.

Hanifah, V.W., A. Priyanti, IGAP Mahendri and R.A. Cramb. 2010. A comparison of feeding management practices of beef cattle smallholders in lowland and upland sites in East Java. Proceedings of The $5^{\text {th }}$ International Seminar on Tropical Animal Production: Community Empowerment and Tropical Animal Industry. October 19-22, 2010. Faculty of Animal Science, Gadjah Mada University, Yogyakarta.

Ishler, V. 2010. Using income over feed costs to manage profitability: the Penn State herd experience 2007-2009. College of Agricultural Sciences, Cooperative Extension. Pennsylvania State University, PA, USA.

Kementan-BPS. 2011. Rilis Hasil Akhir Pendataan Sapi Potong, Sapi Perah dan Kerbau 2011. Kementerian Pertanian dan Badan Pusat Statistik, Jakarta.

Kadir, T.N. 2009. Program Sapi Berlian Propinsi Jawa Timur. Presented paper in Thematic Seminar in $35^{\text {th }}$ Aniversary of Badan Litbang Pertanian, Ministry of Agriculture, Republic of Indonesia: Indonesia Keluar dari Perangkap Impor Sapi Potong. Bogor, August 12, 2009.

Lestari, C.M.S., R. Adiwinarti, M. Arifin and A.
Purnomoadi. 2011. The performance of Java and Ongole crossbred bull under intensive feeding management. J. Indonesian Trop. Anim. Agric. 36(2): 109-113.

Mayulu, H., B. Suryanto, Sunarso, M. Christiyanto, F.I. Ballo and Refa'i. 2009. Feasibility of complete feed based on ammoniated fermented rice straw utilization on the beef cattle farming. J. Indonesian Trop. Anim. Agric. 34(1): 74-80.

Prasetiyono, B.W.H.E., Suryahadi, T. Toharmat and R. Syarief. 2007. Strategi supplementasi protein ransum sapi potong berbasis jerami dan dedak padi. Media Peternakan. 30(3): 207-217.

Purnomoadi, A., B.C. Edy, R. Adiwinarti and E. Rianto. 2007. The performance and energy utilization in Ongole crossbred cattle raised under two level supplementations of concentrate to the rice straw. J. Indonesian Trop. Anim. Agric. 32(1):1-4.

Rianto, E., Nurhidayat and A. Purnomoadi. Pemanfaatan protein pada Sapi Peranakan Ongole dan Sapi Peranakan Ongole $x$ Limousin jantan yang mendapat pakan jerami padi fermentasi dan konsentrat. J. Indonesian Trop. Anim. Agric. 30(3):186191.

SAS Institute Inc. 2006. SAS Guide for Personal Computer, Version 9.04. SAS Institute Inc., Cary, NC.

Soeharsono, R.A. Saptati and K. Diwyanto. 2011. Kinerja sapi persilangan hasil inseminasi buatan dengan bobot awal berbeda. Prosiding, Seminar Nasional Teknologi Peternakan dan Veteriner 2011. Pusat Penelitian dan Pengembangan Peternakan, Bogor. June 7-8, 2011. Page 89-99.

Soeharsono, R.A. Saptati and K. Diwyanto. 2010. Penggemukan sapi lokal hasil inseminasi buatan dan sapi bakalan impor dengan menggunakan bahan pakan lokal. Prosiding Seminar Nasional Teknologi Peternakan dan Veteriner 2010. Pusat Penelitian dan Pengembangan Peternakan, Bogor. August 3-4, 2010. Page 40-46.

Weller, J.I. 1994. Evaluation of Genetic Differences from Profit Equations. In Economic Aspects of Animal Breeding. Chapman \& Hall, London. Page 78-90. 